\title{
Trace and major element contents, microbial communities, and enzymatic activities of urban soils of Marrakech city along an anthropization gradient
}

\author{
Ahmed Naylo ${ }^{1,2}$ - Sofia I. Almeida Pereira ${ }^{3}$ - Leila Benidire ${ }^{1}$. Hicham El Khalil ${ }^{1}$ • Paula M. L. Castro ${ }^{3}$. \\ Stéphanie Ouvrard ${ }^{2} \cdot$ Christophe Schwartz $^{2}$. Ali Boularbah ${ }^{1,4}$
}

Received: 18 September 2018 / Accepted: 9 December 2018 / Published online: 5 January 2019

(C) Springer-Verlag GmbH Germany, part of Springer Nature 2019

\begin{abstract}
Purpose Due to their close proximity with the population, urban soils are extensively affected by human activities that release considerable technogenic inputs resulting in an overall soil degradation and leading to an increase of water-extractable fraction of trace elements. This work aimed to determine the influence of anthropization on trace and major element concentrations and to assess how it might also affect soil biochemical and microbiological parameters in an urban area of Marrakech city, Morocco. Materials and methods The work was carried out on nine topsoils located along an anthropogenic gradient from a suburban area to the city center. The percentage of technogenic fraction (TGF) (e.g., building material, plastic, wood, metallic material, bones, glass, paper, fabric) was used to quantify the degree of human interference in the different soils. Physicochemical parameters were measured: $\mathrm{pH}$ (in water solution), TOC (Anne method), TKN, and Olsen phosphorus. The total fraction of trace and major elements (ISO NF 11446) and their water-soluble fraction were analyzed with an ICP-OES. Enumeration of cultivable microorganisms (bacteria, fungi, actinomycetes) was conducted on culture media. Dehydrogenase, alkaline phosphatase, and urease activities were colorimetrically measured, and the structure and diversity of soil bacterial communities were determined by denaturing gradient gel electrophoresis (DGGE) technique.

Results and discussion In general, trace and major element concentrations showed increasing levels along the anthropogenic gradient, except for $\mathrm{Ca}, \mathrm{Mg}, \mathrm{B}$, and $\mathrm{Cd}$. However, trace element concentrations remained below the standard international limits for soils. Total numbers of microorganisms (bacteria, fungi, and actinomycetes) varied significantly among sites, with bacterial counts directly related to the anthropogenic gradient, significantly increasing from suburban area to the city center. Dehydrogenase activity decreased throughout the anthropogenic gradient, while phosphatase and urease activities varied between sites independently of the gradient. DGGE profiles showed that bacterial diversity was higher in the most anthropized soils, where their community structure seemed to be influenced by the total concentrations of $\mathrm{Zn}, \mathrm{As}, \mathrm{Cr}, \mathrm{Cu}, \mathrm{Ni}, \mathrm{Pb}$, and the technogenic fraction.

Conclusions Overall, trace and major element concentrations and the technogenic fraction were higher with increasing levels of urbanization. Microbiological and biochemical parameters appeared significantly influenced by the anthropogenic inputs without
\end{abstract}

Responsible editor: Yongfu Li

Electronic supplementary material The online version of this article (https://doi.org/10.1007/s11368-018-2221-y) contains supplementary material, which is available to authorized users.

Ali Boularbah

a.boularbah@uca.ac.ma; aliboularbah@gmail.com

1 Faculté des Sciences et Techniques Marrakech, Laboratoire Aliments, Environnement et Santé, Université Cadi-Ayyad, BP 549 Guéliz, 40000 Marrakesh, Morocco

2 INRA, Laboratoire Sols et Environnement, Université de Lorraine, 54000 Nancy, France
3 Centro de Biotecnologia e Química Fina (CBQF), Laboratório Associado, Escola Superior de Biotecnologia, Universidade Católica Portuguesa, Rua Arquiteto Lobão Vital, 172, 4200-374 Porto, Portugal

4 AgrobioSciences Program, Université Mohammed VI Polytechnique (UM6P), Ben Guerir, Morocco 
being systematically inhibited along the anthropogenic gradient. Dehydrogenase activity decreased along the anthropization gradient, and thus may be used as a proxy to assess the effect of anthropization on soil biological functions.

Keywords Ecosystem services · SUITMA's soils $\cdot$ Metal contamination $\cdot$ Soil enzymes $\cdot$ Technogenic fraction $\cdot$ Technogenic soils

\section{Introduction}

Nowadays, urban areas house about $54 \%$ of the population around the world, with expectation to reach $66 \%$ by 2050 (United Nations 2014). Soils in urban areas are strongly affected and modified by human activity, but in turn, they also have a great influence on human life and health (Morel et al. 2005; Levin et al. 2017), thus becoming a research topic of increasing interest worldwide (Burghardt et al. 2015). Urban soils are severely influenced by anthropogenic activities, such as building and industrial activities, road traffic, disposal of liquid and solid wastes, and urban agriculture practices (El Khalil et al. 2008b, 2016; Minnikova et al. 2017). This results in significant changes in soil $\mathrm{pH}$, structure, aeration, water drainage, and nutrient cycles (Morel et al. 2005; El Khalil et al. 2008b, 2013; Joimel et al. 2016). Urban soils may also be considered as the source and sink of large amounts of many organic substances (e.g., polyaromatic hydrocarbons) and trace elements (TE) (e.g., heavy metals) (Meuser 2010; Pouyat et al. 2010), being a major concern to urban environment and public health (Luo et al. 2012). In particular, heavy metals pose a huge risk for human safety with their transfer potential to human tissues through dermal contact absorption, inhalation of soil particles, and consumption of contaminated vegetables (Aeliona et al. 2009; Luo et al. 2012).

Most studies related to urban soils are exclusively focused on their physicochemical characteristics, while their biological properties are generally neglected (Newbound et al. 2010; Joimel et al. 2017). The analysis of biochemical and microbiological parameters along with soil physicochemical properties may constitute an essential tool to quantify soil disturbance due to human interference in urban areas, particularly, soil enzymes that have high sensitivity to anthropogenic disturbances (Filip 2002; Gil-Sotres et al. 2005).

During the last decades, the impact of anthropogenic and technogenic activities on soil microbial communities has been extensively reported (Ding et al. 2016); however, few studies have reported the anthropization effect on bacterial community structure and diversity of urban soils (Hafeez et al. 2012).

In the present study, we have focused on the city of Marrakech, the capital of the Marrakech-Safi region in Morocco, which is inhabited by $1,323,005$ people (Haut-commissariat au plan 2014). The city was built on an oasis and was irrigated by rivers draining towards the Haouz plain, with the palm plant the main tree in Marrakech urban and suburban areas (Wilbaux 2001; El Faiz 2002; El Khalil et al. 2008b).
Until 1912, the evolution of the urban area was confined to the historic center; however, since then, new areas were built outside of the historic city walls (Wilbaux 2001; El Faiz 2002). The accelerated expansion of the city led to the overlap of different land uses including agricultural and industrial activities and domestic waste disposal. Previous work on Marrakech urban soils have demonstrated that human activities have led to an extensive heterogeneity of soils in urban and peri-urban environments (El Khalil et al. 2008b, 2013, 2016). According to El Khalil et al. (2008b), the degree of anthropogenic influence could be mostly related to the content of different technic materials incorporated into soils (14\% in the most anthropized). Moreover, the physical degradation of these technogenic materials increased the water-extractable fraction of TE, enhancing the risk of transfer of metallic contaminants to humans through the food chain (El Khalil et al. 2016).

The present work aimed to evaluate the anthropization impact on both abiotic and biotic soil indicators, namely trace (TE) and major elements (ME) concentrations, soil microbial abundance and enzymatic activities, and on the structure and diversity of soil bacterial communities. We focused on nine topsoils of Marrakech city located along an anthropogenic gradient. The comparison of the physicochemical, biochemical, and microbiological characteristics contributes to our comprehension of the anthropization influence on the biological functioning of urban soils.

\section{Materials and methods}

\subsection{Soil sampling}

Composite soil samples (from five random points) were collected in the upper $20 \mathrm{~cm}$ of nine soils (Fig. 1) during a dry season (June 2014), following a gradient of increasing anthropogenic influence (construction activities rate and the road traffic intensity), ranging from a suburban (site 1-less anthropized) to an urban zone (site 9-most anthropized), according to El Khalil et al. (2008b) (Fig. 2). The construction rate was estimated by evaluating the building density in the sampling sites based on satellite images (Seto et al. 2011). In site 1 , no buildings or residential activities were detected, while site 9 is a large residential area with high building density. Soil samples used for microbiological analyses were sieved $(2 \mathrm{~mm})$ and stored at $4{ }^{\circ} \mathrm{C}$, while soils for chemical 


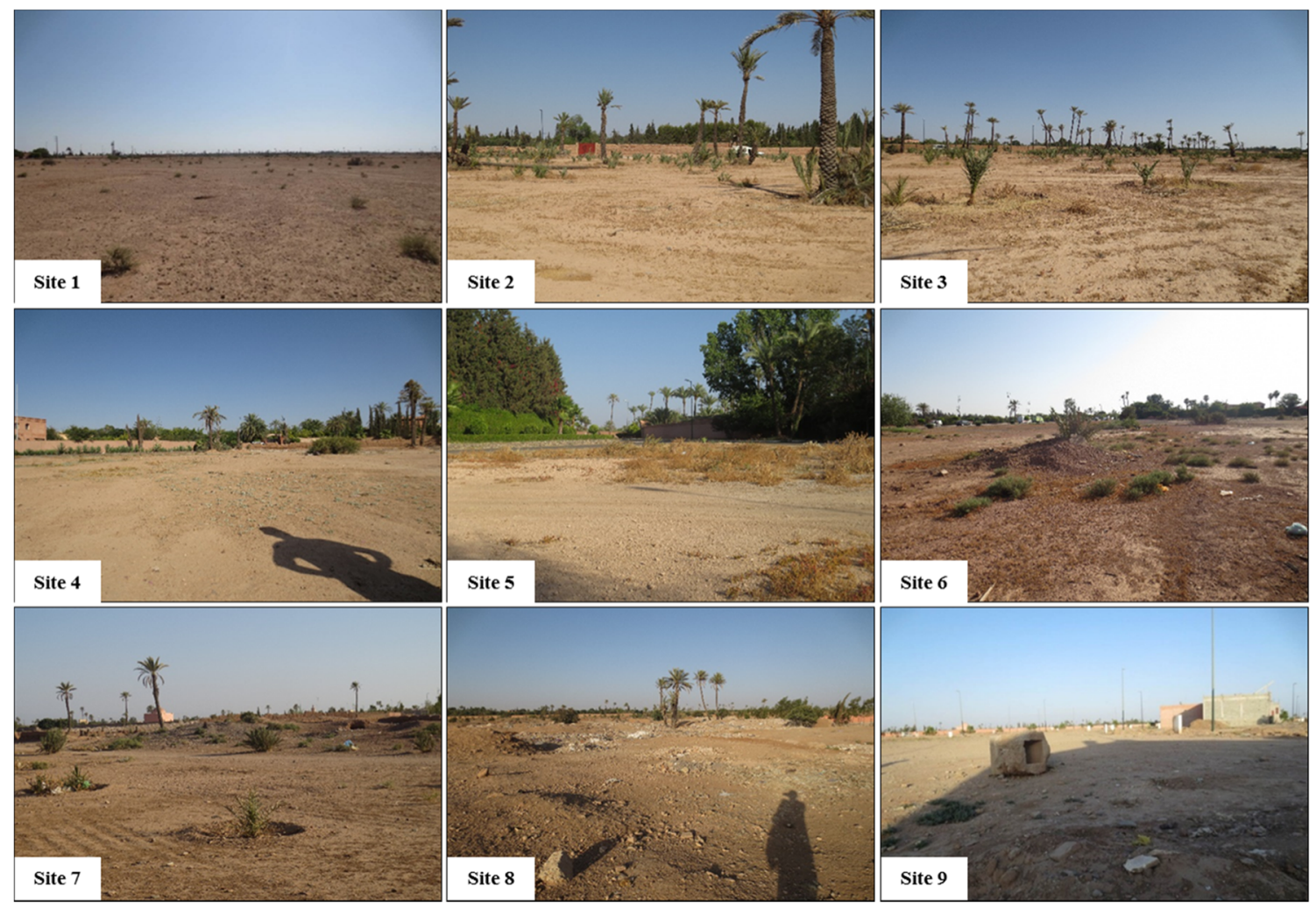

Fig. 1 Localization and observation of the sampling sites, the surface layers, and their technogenic fractions

analyses were air-dried, sieved ( $2 \mathrm{~mm})$, and stored at room temperature.

\subsection{Soil physicochemical properties}

The coarse fraction ( $>2 \mathrm{~mm}$ ) was sorted to separate the different technic materials (technogenic fraction (TGF)) (e.g., building material, plastic, wood, metallic material, bones, glass, paper, fabric) and natural materials (e.g., gravel, rocks) as described by El Khalil et al. (2008b). The percentage of

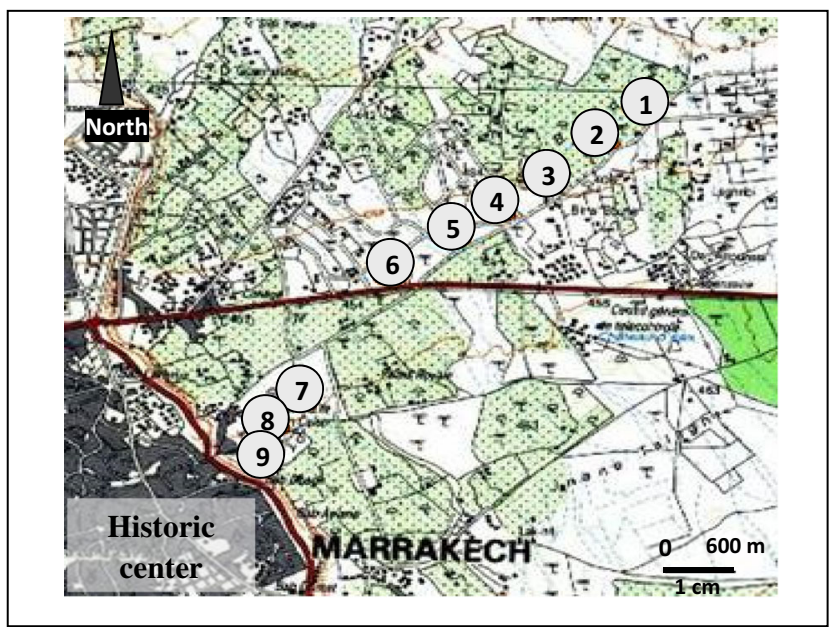

Fig. 2 Sampling sites. Map adapted from Marrakech Al Medina (feuille NH-29-XXIII-3a, 1/50000) (El Khalil et al. 2008b)
TGF was used in this study as a way to quantify the human perturbation level in the different soils.

The $\mathrm{pH}$ of soils was measured in a water suspension (1:2.5 soil/water) using pH meter Jenco 6173 (Alef and Nannipieri 1995). The total organic carbon (TOC) was measured by Anne method (Anne 1945), based on the oxidation of soil organic matter carbon with $\mathrm{K}_{2} \mathrm{Cr}_{2} \mathrm{O}_{7}$. The excess of dichromate was titrated with a solution of ammonium and iron sulfate. The nitrogen $(\mathrm{N})$ content was determined by the Kjeldahl method, based on soil mineralization with sulfuric acid at high temperature. The determination of ammonium in the extract was done by steam distillation. The available $\mathrm{P}$ was measured using the Olsen method (Olsen $\mathrm{P}(\mathrm{OP})$ ), consisting in the extraction of $\mathrm{P}$ from soil with $\mathrm{NaHCO}_{3}$, amount of $\mathrm{P}\left(\mathrm{KH}_{2} \mathrm{PO}_{4}\right)$ was determined by colorimetric method at $820 \mathrm{~nm}$.

\subsection{Total and extractable concentrations of trace and major elements}

The total and extractable concentrations of TE (As, B, Cd, Co, $\mathrm{Cr}, \mathrm{Cu}, \mathrm{Ni}, \mathrm{Pb}, \mathrm{Zn}$ ) and $\mathrm{ME}$ (Al, $\mathrm{Ca}, \mathrm{Fe}, \mathrm{K}, \mathrm{Mg}, \mathrm{Mn}, \mathrm{Na}, \mathrm{S}, \mathrm{P}$ ) were determined in all soil samples.

The total fraction of TE and ME was quantified using the aqua regia mineralization method as described in the ISO NF 11446. Of soil, $0.5 \mathrm{~g}$ was incubated in $8 \mathrm{ml}$ of aqua regia $(6 \mathrm{ml}$ hydrochloric acid $/ 2 \mathrm{ml}$ nitric acid) during $16 \mathrm{~h}$ at room 
temperature and then heated at $100{ }^{\circ} \mathrm{C}$ using a DigiPREP MS (SCP Science) for $2 \mathrm{~h}$. The digest was adjusted to $45 \mathrm{ml}$ with ultrapure water, filtered with a DigiFILTER $(0.45 \mu \mathrm{m})$, and brought up to $50 \mathrm{ml}$ with the same solution.

The extractable fraction of TE and ME was obtained by extracting $10 \mathrm{~g}$ of soil with $25 \mathrm{ml}$ of distilled water. The mixture was shaken ( $15 \mathrm{rpm}$ ) for $2 \mathrm{~h}$ and then filtered. The filtrates were acidified with $1 \%$ of $\mathrm{HNO}_{3}$ before analysis.

TE and ME were analyzed using an inductively coupled plasma (ICP-OES) ThermoFisher, ICAP DUO 6000 at Laboratoire Sols et Environnement, University of Lorraine. Quality control was based on the use of a certified control solution SCP EU-H for all the analyzed elements.

\subsection{Determination of geoaccumulation index $\left(I_{g e o}\right)$}

$I_{\text {geo }}$ was calculated following the equation (Muller 1969):

Igeo $=\log 2\left(\frac{C n}{1.5 \times B n}\right)$

where $C_{n}$ is the measured concentration of the element in environment and $B_{n}$ is the geochemical background value in soil. The values obtained in the less anthropized soil (site 1) were used as background values. The factor 1.5 was introduced to include possible variations of the background matrix correction factor due to lithogenic variations.

According to Muller (1969), the $I_{\text {geo }}$ for each metal is classified as uncontaminated $\left(I_{g e o} \leq 0\right)$, uncontaminated to moderately contaminated $\left(0<I_{\text {geo }} \leq 1\right)$, moderately contaminated $\left(1<I_{\text {geo }} \leq 2\right)$, moderately to heavily contaminated $\left(2<I_{\text {geo }} \leq 3\right)$, heavily contaminated $\left(3<I_{\text {geo }} \leq 4\right)$, heavily to extremely contaminated $\left(4<I_{\text {geo }} \leq 5\right)$, and extremely contaminated $\left(I_{\text {geo }} \geq 5\right)$.

\subsection{Soil enzymatic activities}

The dehydrogenase activity (DHA) was measured by the quantification of the triphenylformazan (TPF) obtained after the incubation of soil with triphenyltetrazolium chloride (TTC) as substrate (Thalmann 1968). Five grams of fresh soil was well mixed with $5 \mathrm{ml}$ of TTC solution $(0.8 \%$ TTC in $0.1 \mathrm{M}$ Tris- $\mathrm{HCl}$ buffer, $\mathrm{pH}$ 7.6) and incubated at $30^{\circ} \mathrm{C}$ for $24 \mathrm{~h}$. The TPF produced was extracted with acetone $(90 \%)$, and the optical density was measured at $546 \mathrm{~nm}$. A blank was prepared by adding $5 \mathrm{~g}$ of fresh soil to $5 \mathrm{ml} 0.1 \mathrm{M}$ Tris-HCl buffer, $\mathrm{pH}$ 7.6. The concentration of TPF was determined by using a standard curve $\left(0\right.$ and $\left.40 \mu \mathrm{g} \mathrm{TPF} \mathrm{ml}^{-1}\right)$.

The alkaline-phosphatase (phosphomonoesterase) activity was quantified by the determination of p-nitrophenol (PNP) resulting from the incubation of p-nitrophenyl phosphate substrate with soil (Tabatabai and Bremner 1969; Eivazi and Tabatabai 1977). One gram of soil, $4 \mathrm{ml}$ of modified universal buffer, and $1 \mathrm{ml}$ of p-nitrophenyl phosphate $(0.015 \mathrm{M})$ were incubated during $1 \mathrm{~h}$ at $37^{\circ} \mathrm{C}$ with shaking, and $1 \mathrm{ml}$ of $\mathrm{CaCl}_{2}(0.5 \mathrm{M})$ and $4 \mathrm{ml}$ of $\mathrm{NaOH}$ $(0.5 \mathrm{M})$ were added. A blank was prepared by adding $1 \mathrm{ml}$ of p-nitrophenyl phosphate after the addition of $1 \mathrm{ml}$ of $\mathrm{CaCl}_{2}$ and $4 \mathrm{ml}$ of $\mathrm{NaOH}$. The optical density was measured at $400 \mathrm{~nm}$. p-Nitrophenol concentration was determined by using a standard curve with concentrations rang-

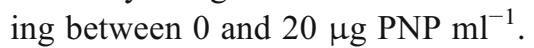

The urease activity was determined in accordance with Tabatabai and Bremner (1972) methodology by the determination of the ammonium concentration produced after soil and urea incubation. Five grams of fresh soil was mixed with $2.5 \mathrm{ml}$ of urea $(0.08 \mathrm{M})$ and incubated for $2 \mathrm{~h}$ at $37{ }^{\circ} \mathrm{C}$ with shaking, followed by adding $50 \mathrm{ml}$ of $\mathrm{KCl}(1 \mathrm{M})$ and left for 30 min with shaking. The ammonium content was determined spectrophotometrically at $690 \mathrm{~nm}$. A blank was made by adding $2.5 \mathrm{ml}$ of distilled water and adding urea solution at the end of the reaction and immediately before $\mathrm{KCl}$ addition. The concentration of $\mathrm{NH}_{4}-\mathrm{N}$ was determined by using a standard curve $\left(0\right.$ and $\left.2.5 \mu \mathrm{g} \mathrm{NH}_{4}-\mathrm{N} \mathrm{ml}^{-1}\right)$.

\subsection{Microbial communities}

\subsubsection{Enumeration of culturable microorganisms}

Microbial enumeration was performed according to Aboudrar et al. (2007). Ten grams of fresh soil was suspended in $90 \mathrm{ml}$ of sterilized saline solution $\left(9 \mathrm{~g} \mathrm{l}^{-1}, \mathrm{NaCl}\right)$. Samples were serially diluted and spread $(0.1 \mathrm{ml})$ in triplicate onto nutrient agar medium for bacteria, potato dextrose agar (PDA) for fungi, and International Streptomyces Project 2 (ISP2) for actinomycete enumeration. After $72 \mathrm{~h}$ of incubation at $28^{\circ} \mathrm{C}$, the number of colony-forming units (CFU) per gram of soil dry weight was counted for each group of microorganisms.

\subsubsection{Denaturing gradient gel electrophoresis analysis}

The soil DNA extraction was realized from a composite soil sample of each site with Power Soil DNA Isolation Kit (MO BIO Laboratories, Inc., USA) according to the manufacturer's instructions and stored at $-20^{\circ} \mathrm{C}$.

For the denaturing gradient gel electrophoresis (DGGE) analysis, the nested PCR reaction conditions were carried out as described previously in Pereira and Castro (2014). In the first amplification, primers 27F (50-GAGTTTGA TCCTGGCTCAG-30) and 1492R (50-ACCTTGTT ACGACTT-30) (NZYTech) were used (Lane 1991) to amplify the bacterial $16 \mathrm{~S}$ rDNA sequence. PCR was conducted in $50 \mathrm{ml}$ content of $1 \times$ PCR buffer (Promega), $2.5 \mathrm{mM}$ $\mathrm{MgCl}_{2}, 0.2 \mathrm{mM}$ of each deoxynucleoside triphosphate (dNTP) (NZYTech), $0.6 \mathrm{mM}$ of each primer, $1.25 \mu \mathrm{l}$ 
DMSO, 0.05 U Taq polymerase (Go Taq-Promega), and $2 \mu \mathrm{l}$ of DNA. After that, the products from the first amplification were used as template using the primers 338F-GC (50-GACTCCTACGGGAGGCAGCAG-30) and 518R (50-ATTACCGCGGCTGCTGG-30) (NZYTech), which amplify the highly variable $\mathrm{V} 3$ region of bacterial $16 \mathrm{~S}$ rRNA gene (Muyzer et al. 1993). The amplification reactions were conducted in $50 \mathrm{ml}$ content of $1 \times$ PCR buffer (Promega), $2.5 \mathrm{mM} \mathrm{MgCl} 2,0.2 \mathrm{mM}$ of each dNTP (NZYTech), $0.6 \mathrm{mM}$ of each primer, $0.05 \mathrm{U}$ Taq polymerase (Go Taq-Promega), and $1 \mathrm{ml}$ of PCR product. PCR products were verified in a $1.5 \%(w / v)$ agarose gel in $1 \times$ TAE buffer.

DGGE gels were run in a DCode Universal Mutation Detection System (Bio-Rad, USA) as previously described in Pereira and Castro (2014). The nest-PCR products (ca. $900 \mathrm{ng}$ of DNA) were loaded in gels contained $8 \%(\mathrm{w} / \mathrm{v})$ polyacrylamide (37:1 acrylamide/bis-acrylamide) in $1 \times$ TAE buffer using a denaturing gradient ranging from 35 to $60 \%$ (7 $\mathrm{M}$ urea and $40 \%$ formamide). In each gel, a DNA ladder (HyperLadder ${ }^{\mathrm{TM}} 100 \mathrm{bp}$-Bioline) was used for internal and external normalization. Electrophoresis was run in $1 \times \mathrm{TAE}$ buffer at $60{ }^{\circ} \mathrm{C}$ temperature, initially at $20 \mathrm{~V}$ during $15 \mathrm{~min}$ and then at $70 \mathrm{~V}$ for $960 \mathrm{~min}$. Gel staining was carried out using $5 \times$ Gel-Green Nucleic Acid Stain solution (Biotium, Inc.) during $10 \mathrm{~min}$. Gel images were captured by a Safe ImagerTM Blue-Light Transilluminator (Invitrogen ${ }^{\mathrm{TM}}$ ) and a micro DOC gel documentation system (Cleaver Scientific Ltd.). Jaccard's similarity coefficient with $1 \%$ tolerance was used for DGGE banding profile comparison while they were clustered using unweighted pair group methodology with arithmetic averages (UPGMA) (Moreira et al. 2014), using the Bionumerics ${ }^{\circledR}$ software (version 6.6; Applied Maths, StMartens-Laten, Belgium, version 6.6).

\subsection{Statistical analyses}

All statistical analyses were carried out with SPSS 21.0 software package (SPSS, Inc., Chicago, IL, USA). The data were analyzed through analysis of variance (ANOVA), and the statistical significance of differences $(P<0.05)$ between means was set through Tukey post hoc test. Pearson's correlations were made between different variables.

Banding profiles were converted onto a matrix of presence/ absence (Moreira et al. 2014), and a canonical correspondence analysis (CCA) was performed to link bacterial communities to some physicochemical characteristics using PC-ORD (MJM Software, Gleneden, USA, version 5). Shannon-Wiener $\left(H^{\prime}\right)$ index was determined depending on DGGE band intensity imitated as peak heights in the densitometric curve, with Eq. (1):

$H^{\prime}=-\sum\left(n_{i} / N\right) \cdot \log \left(n_{i} / N\right)$

where $n_{i}$ is the height of the peak and $N$ is the sum of all peak heights of the densitometric curve (Boon et al. 2001).

\section{Results}

\subsection{Physicochemical parameters}

The physicochemical characteristics of the topsoils collected in the nine sites along the anthropogenic gradient are presented in Table 1. The $\mathrm{pH}$ of all soils was found to be around neutral, ranging from slightly acidic (6.77 in soil 1) to slightly basic (7.71 in soil 5) without notable differences between sites. The water content of soils never exceeded $2 \%$, varying between $0.82 \%$ in soil 7 and $1.92 \%$ in soil 5 , however without a clear trend along the anthropogenic gradient. TGF increased clearly along the anthropogenic gradient. No trace of technic

Table 1 Physicochemical characteristics of the soils recovered from the different sites

\begin{tabular}{|c|c|c|c|c|c|c|c|}
\hline Sites & $\mathrm{pH}$ & Water content $\%$ & $\begin{array}{l}\text { Technogenic fraction } \\
\text { (TGF) } \%\end{array}$ & Total organic carbon $\%$ & $\mathrm{TKN} \%$ & $\begin{array}{l}\text { Total phosphorus } \\
\left(\mathrm{mg} \mathrm{g}^{-1}\right)\end{array}$ & $\begin{array}{l}\text { Olsen phosphorus } \\
\left(\mathrm{mg} \mathrm{g}^{-1}\right)\end{array}$ \\
\hline 1 & 6.77 & 1.00 & 0.00 & $0.84 \pm 0.38 b$ & $0.06 \pm 0.03 b$ & 0.61 & $0.025 \pm 0.008 \mathrm{~d}$ \\
\hline 2 & 7.27 & 1.27 & 2.60 & $0.87 \pm 0.25 b$ & $0.08 \pm 0.03 b$ & 1.10 & $0.030 \pm 0.009 \mathrm{c}, \mathrm{d}$ \\
\hline 3 & 7.41 & 1.67 & 2.88 & $0.76 \pm 0.38 \mathrm{~b}, \mathrm{c}$ & $0.05 \pm 0.03 b$ & 0.69 & $0.029 \pm 0.011 \mathrm{c}, \mathrm{d}$ \\
\hline 4 & 7.52 & 1.17 & 1.99 & $0.62 \pm 0.34 b, c, d$ & $0.04 \pm 0.01 b$ & 0.78 & $0.034 \pm 0.013 b, c$ \\
\hline 5 & 7.71 & 1.92 & 10.75 & $0.46 \pm 0.12 \mathrm{c}, \mathrm{d}$ & $0.06 \pm 0.01 b$ & 0.96 & $0.028 \pm 0.010 \mathrm{c}, \mathrm{d}$ \\
\hline 6 & 7.70 & 1.37 & 6.78 & $0.70 \pm 0.05 b, c, d$ & $0.05 \pm 0.02 b$ & 1.66 & $0.030 \pm 0.013 \mathrm{c}, \mathrm{d}$ \\
\hline 7 & 7.53 & 0.82 & 10.34 & $1.71 \pm 0.33 \mathrm{a}$ & $0.16 \pm 0.02 \mathrm{a}$ & 1.60 & $0.140 \pm 0.006 \mathrm{a}$ \\
\hline 8 & 7.05 & 1.25 & 12.94 & $0.19 \pm 0.06 \mathrm{~d}$ & $0.15 \pm 0.01 \mathrm{a}$ & 1.03 & $0.041 \pm 0.010 \mathrm{~b}$ \\
\hline 9 & 7.45 & 1.67 & 35.02 & $0.76 \pm 0.29 b, c$ & $0.20 \pm 0.04 \mathrm{a}$ & 1.78 & $0.029 \pm 0.012 \mathrm{c}, \mathrm{d}$ \\
\hline
\end{tabular}

Means $(n=3)$ in same column with different letters are significantly different from each other $(P<0.05)$ according to the Tukey test $T K N$ total Kjeldahl nitrogen 
materials was found in soil 1, while the TGF reached $35 \%$ in soil 9 for which it was considered a Technosol (IUSS 2015). The TOC varied widely and independently of the anthropogenic gradient $(P<0.05)$, ranging between $0.19 \%$ in soil 8 and $1.71 \%$ in soil 7 . The TKN ranged between $0.04 \%$ in soil 4 and $0.20 \%$ in soil 9 . The variation between sites was very weak but showed to be significant $(P<0.05)$ and correlated to the gradient of anthropization. Total and available phosphorus $($ Olsen $\mathrm{P})$ contents also varied significantly between sites $(P<0.05)$, ranging from $0.61 \mathrm{mg} \mathrm{g}^{-1}$ in soil 1 to $1.78 \mathrm{mg} \mathrm{g}^{-1}$ in soil 9 and from $0.025 \mathrm{mg} \mathrm{g}^{-1}$ in soil 1 to $0.140 \mathrm{mg} \mathrm{g}^{-1}$ in soil 7 , respectively. A general increase of total phosphorus was observed in soils along the anthropogenic gradient.

Total concentration of TE varied between 45.22 and $126.25 \mathrm{mg} \mathrm{kg}^{-1}$ for $\mathrm{Zn}, 6.65$ and $10.18 \mathrm{mg} \mathrm{kg}^{-1}$ for As, 9.31 and $22.13 \mathrm{mg} \mathrm{kg}^{-1}$ for $\mathrm{B}, 0.13$ and $0.28 \mathrm{mg} \mathrm{kg}^{-1}$ for $\mathrm{Cd}, 7.49$ and $11.89 \mathrm{mg} \mathrm{kg}^{-1}$ for $\mathrm{Co}, 21.39$ and $42.21 \mathrm{mg} \mathrm{kg}^{-1}$ for $\mathrm{Cr}, 14.16$ and $71.69 \mathrm{mg} \mathrm{kg}^{-1}$ for $\mathrm{Cu}$, 12.75 and $20.42 \mathrm{mg} \mathrm{kg}^{-1}$ for $\mathrm{Ni}$, and 10.04 and $73.69 \mathrm{mg} \mathrm{kg}^{-1}$ for $\mathrm{Pb}$ (Table 2). Excepting $\mathrm{Cd}$ and $\mathrm{B}$, the total concentrations of TE increased with human interference rate. Indeed, the TGF was highly positively correlated to $\mathrm{Cu}(r=$ $0.954 * *), \mathrm{Pb}\left(r=0.899^{* *}\right), \mathrm{Cr}(r=0.874 * *)$, and As $(r=$ $0.718^{*}$ ) (Online resource 1). The water-soluble fractions of most TE were very low and in most cases were below the detection limit.

The calculated average values of $I_{\text {geo }}$ of TE decreased for urban soils with the following trend $\mathrm{Pb}>\mathrm{Cu}>\mathrm{Zn}>\mathrm{As}>\mathrm{Ni}>$ $\mathrm{Cr}>\mathrm{Co}>\mathrm{B}>\mathrm{Cd}$ (Table 3 ). $\mathrm{Pb}$ and $\mathrm{Cd}$ had, respectively, the highest and lowest values of $I_{g e o}$. Based on the $I_{g e o}$ values, the studied urban soils of Marrakech were classified as moderately to heavily contaminated with $\mathrm{Pb}$ and moderately contaminated with $\mathrm{Cu}$ and $\mathrm{Zn}$. Despite the presence of TGF in the different sites, the $I_{\text {geo }}$ values for $\mathrm{As}, \mathrm{Ni}, \mathrm{Cr}, \mathrm{Co}, \mathrm{B}$, and $\mathrm{Cd}$ were negative, which might be due to the low background concentrations and to a deficient enrichment of these elements (Charzyński et al. 2017; Ita and Anwana 2017).

Total concentrations of ME varied between 13.11 and $16.37 \mathrm{~g} \mathrm{~kg}^{-1}$ for Al, 22.36 and $94.72 \mathrm{~g} \mathrm{~kg}^{-1}$ for $\mathrm{Ca}, 19.32$ and $30.43 \mathrm{~g} \mathrm{~kg}^{-1}$ for $\mathrm{Fe}, 2.83$ and $6.77 \mathrm{~g} \mathrm{~kg}^{-1}$ for $\mathrm{K}, 7.03$ and $23.28 \mathrm{~g} \mathrm{~kg}^{-1}$ for $\mathrm{Mg}, 0.32$ and $0.89 \mathrm{~g} \mathrm{~kg}^{-1}$ for $\mathrm{Mn}, 0.28$ and $1.26 \mathrm{~g} \mathrm{~kg}^{-1}$ for $\mathrm{Na}$, and between 0.17 and $3.83 \mathrm{~g} \mathrm{~kg}^{-1}$ for $\mathrm{S}$.

Total concentrations were high in all sites (Table 4), generally following the geochemical background (El Khalil et al. 2013), with an overall increase along the anthropogenic gradient, which was corroborated by the positive correlations found between the TGF and $\mathrm{S}(r=0.912 * *)$ and $\mathrm{Na}(r=$ 0.904**) (Online resource 1).

The water-soluble fractions of ME were higher than those recorded for TE, ranging between $<0.0115$ and $0.0147 \mathrm{mg} \mathrm{kg}^{-1}$ for Al, 80.98 and $1965.75 \mathrm{mg} \mathrm{kg}^{-1}$ for $\mathrm{Ca}$, $<0.005$ and $0.0238 \mathrm{mg} \mathrm{kg}^{-1}$ for $\mathrm{Fe}, 43.3$ and $399.75 \mathrm{mg} \mathrm{kg}^{-1}$

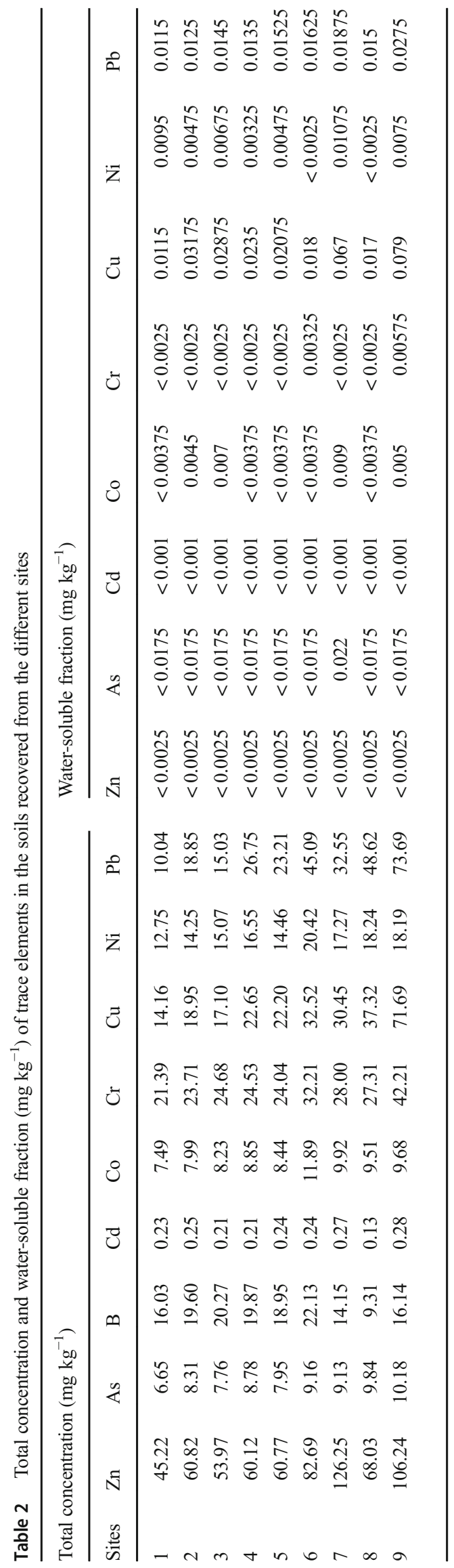


Table 3 Geoaccumulation index $\left(I_{\text {geo }}\right)$ of trace elements of soils recovered from sites 2 to 9

\begin{tabular}{llllllllll}
\hline & As & $\mathrm{B}$ & $\mathrm{Cd}$ & $\mathrm{Co}$ & $\mathrm{Cr}$ & $\mathrm{Cu}$ & $\mathrm{Ni}$ & $\mathrm{Pb}$ & $\mathrm{Zn}$ \\
\hline Mean & -0.17 & -0.50 & -0.63 & -0.28 & -0.21 & 0.42 & -0.20 & 1.06 & 0.13 \\
Range & $(-0.36)-0.03$ & $(-1.37)-(-0.12)$ & $(-1.41)-(-0.30)$ & $(-0.49)-0.08$ & $(-0.44)-0.40$ & $(-0.31)-1.75$ & $(-0.42)-0.09$ & $0.00-2.29$ & $(-0.33)-0.90$
\end{tabular}

for $\mathrm{K}, 15.47$ and $113.2 \mathrm{mg} \mathrm{kg}^{-1}$ for $\mathrm{Mg}, 0.0053$ and $0.223 \mathrm{mg} \mathrm{kg}^{-1}$ for $\mathrm{Mn}, 35.9$ and $640.25 \mathrm{mg} \mathrm{kg}^{-1}$ for $\mathrm{Na}$, and between 7.55 and $1350.75 \mathrm{mg} \mathrm{kg}^{-1}$ for S (Table 4).

\subsection{Microbial enumeration}

Plate counts indicated that the nine topsoils harbored various classes of cultivable microorganisms with a higher relative abundance of bacteria (Table 5). Bacterial numbers increased significantly $(P<0.05)$ along the gradient of anthropization ( $47.14 \times 10^{3}$ in site 1 to $162.73 \times 10^{3} \mathrm{CFU} \mathrm{g}^{-1}$ in site 9$)$, being positively correlated to TGF $\left(r=0.699^{*}\right)$. Fungi and actinomycete CFUs also varied significantly $(P<0.05)$ between the different sites, however without a defined trend. They ranged from $6.75 \times 10^{2}$ in site 4 to $69.76 \times 10^{2} \mathrm{CFU} \mathrm{g}^{-1}$ in site 8 and from $52.23 \times 10^{2}$ in site 4 to $170.64 \times 10^{2} \mathrm{CFU} \mathrm{g}^{-1}$ in site 3 , for fungi and actinomycetes, respectively.

\subsection{Soil enzymes}

The urban soils collected along the gradient of anthropization exhibited multiple degrees of enzymatic activities (Fig. 3). The DHA activity decreased significantly $(P<0.05)$ throughout the anthropogenic gradient, especially from site 2 to site 8 . The activity of phosphatase also varied significantly $(P<0.05)$ between sites, however, without a defined trend. The lowest activity was observed in site $5\left(3.76 \mu \mathrm{g} \mathrm{PNP} \mathrm{g}^{-1}\right.$ dry soil $\mathrm{h}^{-1}$ ), while the highest activity was recoded in site 7 $\left(116.93 \mu \mathrm{g} \mathrm{PNP} \mathrm{g}^{-1}\right.$ dry soil $\left.\mathrm{h}^{-1}\right)$. The urease activity varied significantly $(P<0.05)$ between locations, ranging from 8.66 in site 3 to $45.30 \mu \mathrm{g} \mathrm{NH}_{4}-\mathrm{N} \mathrm{g}^{-1}$ dry soil h${ }^{-1}$ in site 7 .

\subsection{Bacterial community structure}

Generally, DGGE patterns (Fig. 4) exhibited a different number of bands in each soil. The higher number of bands (22) was found in soil 7, while soil recovered from site 6 showed the lowest number (11), which is corroborated by the ShannonWiener index $\left(H^{\prime}\right)$ determined. Overall, $H^{\prime}$ revealed a higher bacterial diversity in soils collected close to the city center (more anthropized area: S7, S8, and S9) than in soils from the less anthropized area, with the exception of site 5 that was similar to the abovementioned soils. DGGE profiles revealed differences in bacterial community structure (BCS) among soils collected along the anthropogenic gradient (Fig. 4). Bacterial communities clustered into three main groups (Fig. 4). The first group includes soils collected from the less anthropized area (S2, S3, and S4), the second group comprises soils 5 and 6, while the third group aggregates the highly anthropized soils (sites 8 and 9). Site 1 was related to the first and second groups, while the bacterial communities present in site 7 clearly differed from those of the other sites. CCA ordination is shown in Fig. 5 and explains $46.4 \%(P<0.01)$ of the variation in the first two components. CCA analysis also shows that the structure of bacterial communities is correlated to the anthropogenic gradient. As for the cluster analysis, site 7 stands out from the other sites, while most anthropized sites (S8 and S9) were grouped together, as well as soils from S5 and S6 and soils from less

Table 4 Total concentration and water-soluble fraction of major elements in the soils recovered from the different sites

\begin{tabular}{|c|c|c|c|c|c|c|c|c|c|c|c|c|c|c|c|c|}
\hline \multirow[b]{2}{*}{ Sites } & \multicolumn{8}{|c|}{ Total concentrations $\left(\mathrm{g} \mathrm{kg}^{-1}\right)$} & \multicolumn{8}{|c|}{ Water-soluble fraction $\left(\mathrm{mg} \mathrm{kg}^{-1}\right)$} \\
\hline & $\mathrm{Al}$ & $\mathrm{Ca}$ & $\mathrm{Fe}$ & K & $\mathrm{Mg}$ & $\mathrm{Mn}$ & $\mathrm{Na}$ & $\mathrm{S}$ & $\mathrm{Al}$ & $\mathrm{Ca}$ & $\mathrm{Fe}$ & $\mathrm{K}$ & $\mathrm{Mg}$ & $\mathrm{Mn}$ & $\mathrm{Na}$ & $\mathrm{S}$ \\
\hline 1 & 13.11 & 73.55 & 19.33 & 3.88 & 17.01 & 0.32 & 0.28 & 0.17 & $<0.0115$ & 80.975 & 0.0085 & 43.3 & 15.47 & 0.007 & 35.90 & 7.55 \\
\hline 2 & 14.31 & 71.21 & 21.34 & 4.30 & 14.02 & 0.39 & 0.44 & 0.31 & 0.01175 & 127.4 & 0.00825 & 70.08 & 25.35 & 0.014 & 167.65 & 19.06 \\
\hline 3 & 15.80 & 66.29 & 22.69 & 5.00 & 14.24 & 0.41 & 0.43 & 0.26 & $<0.0115$ & 124.975 & $<0.005$ & 72.00 & 26.98 & 0.021 & 173.98 & 15.13 \\
\hline 4 & 15.87 & 57.25 & 24.09 & 4.84 & 14.12 & 0.47 & 0.65 & 0.39 & $<0.0115$ & 375.5 & $<0.005$ & 148.20 & 67.38 & 0.029 & 329.25 & 77.00 \\
\hline 5 & 15.86 & 94.72 & 21.78 & 5.16 & 23.28 & 0.43 & 0.46 & 0.27 & $<0.0115$ & 131.975 & $<0.005$ & 77.82 & 35.48 & 0.019 & 124.28 & 30.60 \\
\hline 6 & 23.08 & 52.25 & 30.43 & 6.77 & 14.72 & 0.89 & 0.52 & 0.27 & $<0.0115$ & 170.1 & $<0.005$ & 62.30 & 28.55 & 0.0053 & 155.50 & 19.59 \\
\hline 7 & 15.76 & 49.82 & 27.21 & 4.06 & 11.44 & 0.55 & 0.36 & 0.44 & 0.013 & 190.875 & 0.0238 & 107.60 & 28.08 & 0.064 & 75.63 & 33.80 \\
\hline 8 & 14.28 & 22.36 & 28.75 & 2.83 & 7.03 & 0.50 & 0.49 & 0.30 & 0.0147 & 698.5 & $<0.005$ & 78.60 & 82.08 & 0.075 & 251.00 & 195.80 \\
\hline 9 & 16.37 & 55.40 & 26.79 & 5.00 & 9.69 & 0.57 & 1.26 & 3.83 & $<0.0115$ & 1965.75 & $<0.005$ & 399.75 & 113.2 & 0.223 & 640.25 & 1350.75 \\
\hline
\end{tabular}


Table 5 Bacterial, fungi, and actimomycete CFUs per gram of soil recovered from the different sites

\begin{tabular}{llll}
\hline Sites & $\begin{array}{l}\text { Bacteria }\left(\times 10^{3} \mathrm{CFU} \mathrm{g}^{-1} \text { dry }\right. \\
\text { soil })\end{array}$ & $\begin{array}{l}\text { Fungi }\left(\times 10^{2} \mathrm{CFU} \mathrm{g}{ }^{-1} \text { dry }\right. \\
\text { soil })\end{array}$ & $\begin{array}{l}\text { Actinomycetes }\left(\times 10^{2} \mathrm{CFU} \mathrm{g}{ }^{-1} \text { dry }\right. \\
\text { soil })\end{array}$ \\
\hline 1 & $47.14 \pm 3.09 \mathrm{~b}, \mathrm{c}$ & $13.47 \pm 5.83 \mathrm{~b}, \mathrm{~d}$ & $83.05 \pm 20.57 \mathrm{~b}, \mathrm{c}$ \\
2 & $72.93 \pm 1.75 \mathrm{~b}$ & $24.76 \pm 7.03 \mathrm{~b}$ & $69.78 \pm 10.32 \mathrm{c}$ \\
3 & $44.07 \pm 14.71 \mathrm{c}$ & $31.64 \pm 16.72 \mathrm{~b}$ & $170.64 \pm 15.29 \mathrm{a}$ \\
4 & $22.26 \pm 1.75 \mathrm{c}$ & $6.75 \pm 0.00 \mathrm{~d}$ & $52.23 \pm 7.16 \mathrm{c}$ \\
5 & $76.81 \pm 4.12 \mathrm{~b}$ & $6.80 \pm 3.40 \mathrm{c}, \mathrm{d}$ & $83.84 \pm 22.63 \mathrm{~b}, \mathrm{c}$ \\
6 & $109.51 \pm 37.02 \mathrm{a}$ & $16.90 \pm 9.56 \mathrm{~b}, \mathrm{~d}$ & $74.36 \pm 37.64 \mathrm{c}$ \\
7 & $131.08 \pm 8.96 \mathrm{a}$ & $23.53 \pm 3.36 \mathrm{~b}$ & $118.76 \pm 16.92 \mathrm{~b}$ \\
8 & $119.16 \pm 28.74 \mathrm{a}$ & $69.76 \pm 24.88 \mathrm{a}$ & $166.53 \pm 30.63 \mathrm{a}$ \\
9 & $162.73 \pm 29.28 \mathrm{a}$ & $18.65 \pm 2.40 \mathrm{~b}, \mathrm{c}$ & $77.97 \pm 10.17 \mathrm{c}$ \\
\hline
\end{tabular}

Means $(\mathrm{n}=3)$ in same column with different letters are significantly different from each other $(\mathrm{P}<0.05)$ according to the Tukey test

$C F U$ colony-forming unit anthropized sites (S2, S3, and S4). In addition, CCA analysis revealed that the total concentration of the TE $\mathrm{Zn}, \mathrm{As}, \mathrm{Ni}, \mathrm{Pb}$, $\mathrm{Cr}$, and $\mathrm{Cu}$, as well as the TGF present in each soil, influenced the BCS in the most anthropized soils (S8 and S9).

\section{Discussion}

Due to their close proximity with population, urban soils are heavily altered by anthropogenic and technogenic activities as they receive considerable non-natural inputs (e.g., technic materials) from industry, traffic, construction, and refuse (Lorenz et al. 2006; El Khalil et al. 2008b, 2016) leading to soil degradation. In the present work, the physicochemical, biochemical, and microbiological properties of the soils were clearly influenced by the anthropogenic gradient, with an increase in TE and ME concentrations and a concomitant decrease in soil DHA activity throughout the anthropogenic gradient (from site 1 to site 9). In addition, the structure of the bacterial communities seems to be related to the gradient of anthropization and the physicochemical conditions of each site.

In the present work, the increase of the anthropization rate of soils had a strong effect on their morphology and physical characteristics. The strong heterogeneity of soils was confirmed by the high percentages of TGF, especially in sites 8 $(12.94 \%)$ and $9(35.02 \%)$. Both soils in sites 8 and 9 suffered a technogenic transformation leading to a higher abundance of coarse fractions (natural and technogenic). This pattern was on the opposite of what was observed on non-anthropized soils (site 1) characterized by the abundance of the fine fraction. These morphological changes are the result of transportation, and transformation processes occurring in urban soils, as well as the incorporation of exogenous materials into soils resulting from building activities. Similar results were reported by Jim (1998) and Hulisz et al. (2018).
The $\mathrm{pH}$ of soils collected from Marrakech urban and suburban areas was neutral to slightly alkaline, which is common for urban soils. Several studies have shown that acidity decreases with anthropization (Klose and Makeschin 2004; Godefroid et al. 2007; Magiera et al. 2007) under the effect of alkaline materials, such as industrial ash emissions and dust from construction, roadways, and demolition (Klose and Makeschin 2004; Godefroid et al. 2007; Magiera et al. 2007). In this work, TOC did not increase along the anthropogenic gradient, despite its concentration varying significantly between locations. This finding is not in agreement with other authors' results, who generally reported an increase of TOC due to anthropization and changes according to land use (Pouyat et al. 2009; Raciti et al. 2011; Bae and Ryu 2015). Nannoni et al. (2014) reported TOC percentages between $0.59 \%$ and $4.07 \%$ in soils of urban zones of Siena municipality (Italy). Similarly, Hafeez et al. (2012) showed TOC values between $7.95 \%$ and $15.6 \%$ in highly anthropized soils (Technosols). However, in this work, TOC values generally did not exceed $1 \%$, being highly below the values above described, which may be related to the type of technic materials (e.g., cement, brick, glass, bones) present in the nine sites (El Khalil et al. 2008b). In this work, an increase of TE concentrations in the soils along the anthropogenic gradient, with exception for B and Cd, was observed. These results are in agreement with previous works where TE concentrations increased in soils subjected to anthropogenic and technogenic activities (Yuangen et al. 2006; Gülser and Erdoğan 2008; Papa et al. 2010; El Khalil et al. 2008b, 2013). The concentrations of $\mathrm{Zn}, \mathrm{Cu}, \mathrm{Ni}$, and $\mathrm{Cd}$ determined were lower than those measured 10 years prior to this work in the same studied sites of Marrakech (El Khalil et al. 2008b). These differences may be related to the potential leaching of these elements to the deeper layers of soil profiles during the rainy season (Concas et al. 2006; El Khalil et al. 2008a), and also to the constant interference of human activities (Bullock and 

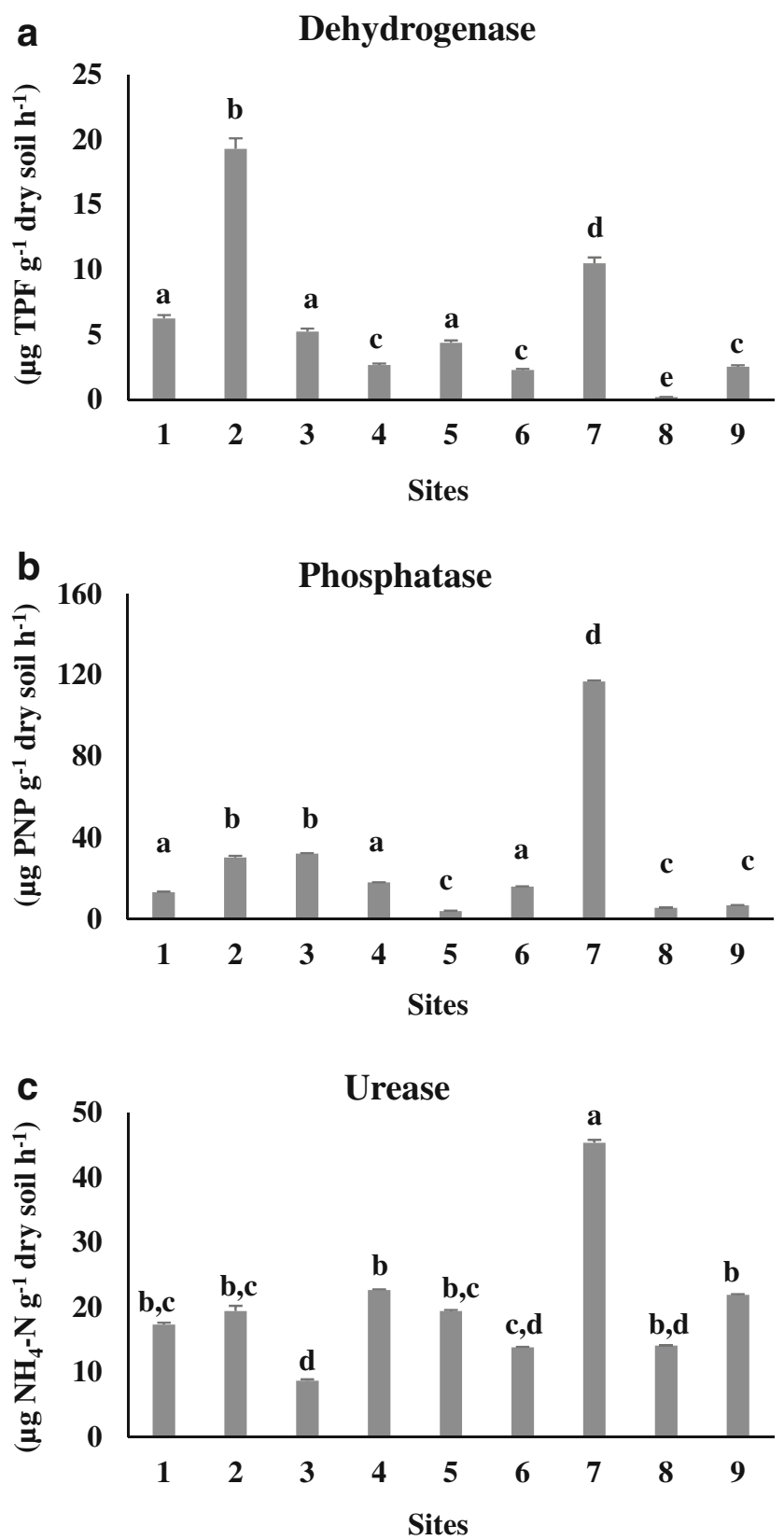

Fig. 3 Enzymatic activities recorded in the nine soils. Dehydrogenase activity (a). Phosphatase activity (b). Urease activity (c). TPF triphenyltetrazolium formazan, PNP p-nitrophenol. Means with different letters are significantly different from each other $n=3$, $P<0.05$ according to the Tukey test

Gregory 1991; Morel et al. 2005). The water-soluble fractions of $\mathrm{TE}$ were very low for $\mathrm{Pb}, \mathrm{Cu}$, and $\mathrm{Ni}$ and below detection limits for $\mathrm{Zn}, \mathrm{As}, \mathrm{Co}, \mathrm{Cr}$, and $\mathrm{Cd}$, which may be related to the slightly alkaline $\mathrm{pH}$ found in the studied soils (Farrell et al. 2010). The total TE contents determined in the nine soils are within the range of those measured in agricultural and garden soils in and around Marrakech city (unpublished data), but they are very low in comparison to mining soil contents in the vicinity of the city (Boularbah et al. 2006; Benidire et al.
2016). Moreover, these levels of TE did not exceed the international limits described in the Canadian guidelines for soil residential/parkland and agricultural use (Kabata-Pendias 2011). Although the concentrations of TE were within international standards, the concentrations determined for $\mathrm{As}, \mathrm{Cu}$, $\mathrm{Pb}$, and $\mathrm{Zn}$ in the most anthropized soils may be harmful to human health, especially for children (Gevorgyan et al. 2017; $\mathrm{Hu}$ et al. 2017). The calculated $I_{g e o}$ showed that $\mathrm{Pb}$ was the main inorganic contaminant in the studied urban soils. They were moderately contaminated with $\mathrm{Cu}$ and $\mathrm{Zn}$, which was corroborated by several works (Charzyński et al. 2017; Ita and Anwana 2017). These TEs have been reported as major urban contaminants (Yang and Zhang 2015). The main sources of these elements are the vehicle exhaust gases, tire wear, combustion of lubricating oils, corrosion of metal objects, and leaching from building materials (e.g., bricks, lead carbonate paints, concrete, galvanized metals) (Davis et al. 2001; Yesilonis et al. 2008; Rauch and Pacyna 2009), which correspond to the dominant TGF and activities in the area of the studied soils. The enrichment of urban soils with the mentioned elements predisposes the local population, especially children, to serious health risks, such as cancers and genetic deformation (Baldwin and Marshall 1999; Laidlaw and Filippelli 2008). TE contamination can also decrease the ability of urban soils to provide ecosystem services (Morel et al. 2015).

Therefore, the involvement of local authorities in the continuous monitoring of these sites is of highest priority to avoid any excess of toxic elements in soils, thereby ensuring the safety of the population.

Overall, total and extractable concentrations of ME increased along the anthropogenic gradient, which may be explained by the geochemical background of Marrakech soils (El Khalil et al. 2013) as well as by the higher human activities in most anthropized soils. Similarly, other authors reported an increase of ME contents in soils near anthropogenic activities, reaching high concentrations in highly anthropized soils (Lovett et al. 2000; Klose and Makeschin 2004; El Khalil et al. 2013; Alekseenko and Alekseenko 2014; Joimel et al. 2016).

In the present work, the numbers of bacteria determined in the topsoils of the nine sites were very low $\left(0.22\right.$ to $\left.1.6 \times 10^{5} \mathrm{CFUs} \mathrm{g}^{-1}\right)$ in comparison to the results obtained by Braun et al. (2006) and Margesin et al. (2011) which reported 5.9 and 231 times more bacteria in urban and in metal-contaminated soils, respectively. CFU counts for fungi and actinomycetes were also below the numbers obtained by Oliveira and Pampulha (2006) in metal-contaminated $\left(2.8 \times 10^{5} \mathrm{CFU} \mathrm{g}^{-1}\right.$ and $83 \times 10^{4} \mathrm{CFU} \mathrm{g}^{-1}$, respectively) soils and by Hayat et al. (2002) in soils receiving treated wastewaters $\left(2.8 \times 10^{5} \mathrm{CFU} \mathrm{g}^{-1}\right.$ and $1.7 \times 10^{5} \mathrm{CFU} \mathrm{g}^{-1}$, respectively). 
Fig. 4 Similarity of the bacterial community of soils from different sites based on the UPGMA clustering method. Sites $1-9$. $H^{\prime}$ Shannon index

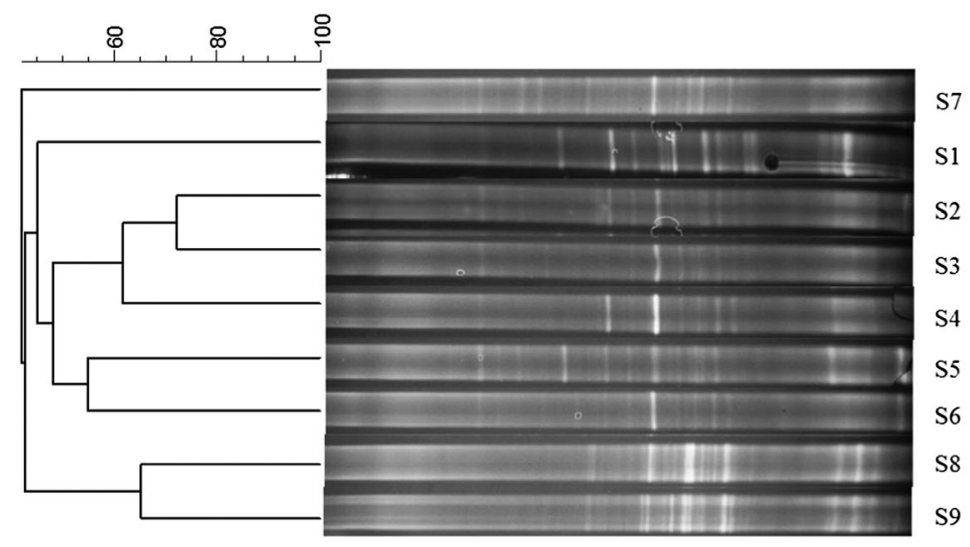

Bands (n) $\boldsymbol{H}^{\prime}$ S7 $\quad 22$ 1.341 1.145 1.204 1.176 1.074 1.300 1.039 1.275 1.275
These outcomes could be due to some of the physicochemical characteristics of our studied soils in particular the low TOC percentage, water content, and TKN, as well as the semi-arid climate of the region. However, bacterial numbers increased along the anthropogenic gradient, and they were positively correlated to some TE and ME, namely total $\mathrm{P}\left(r=0.878^{* *}\right), \mathrm{Fe}\left(r=0.679^{*}\right), \mathrm{Zn} \quad(r=$ $\left.0.810^{* *}\right), \mathrm{Cr}\left(r=0.804^{* *}\right)$, and $\mathrm{Cu}\left(r=0.828^{* *}\right)$ (Online resource 1). These results showed a stimulating effect of trace metallic elements on bacterial counts, which is corroborated by Dai et al. (2004) and Stefanowicz et al. (2012). TE can be useful for bacterial metalloenzyme activities, which have a key role in microbial growth and metabolism (Gadd 1992), while ME are nutrients that stimulate microbial concentrations in soils (Lalande et al. 2009).
Dehydrogenase activity constitutes an important indicator of total microbial activity ( $\mathrm{Gu}$ et al. 2009; Salazar et al. 2011; Wolińska and Stęniewska 2012; Minnikova et al. 2017). In this work, DHA was negatively affected by the anthropization rate, since its activity in general decreased along the anthropogenic gradient and was negatively correlated to TGF $(r=-0.416)$ and to TE and ME (Online resource 1). This decrease may be related to the constant input of organic (e.g., polycyclic aromatic hydrocarbons) and inorganic (e.g., metals) pollutants, resulting from urban activities (construction of buildings and infrastructures, traffic, and waste management). Indeed, TE may negatively affect soil microbiology and enzymatic activity, since metallic pollutants may interact with the enzyme-substrate complex, denaturing the enzyme protein or interacting with the protein-active groups (Pan and Yu 2011). Similarly, Li et al.
Fig. 5 Canonical correspondence analysis (CCA) of the DGGE bacterial community from the soils collected in the nine sites. The figure shows the relationship among samples from the DGGE profiles and some

physicochemical parameters measured in soils S1 to S9. The first axis accounted for $25.6 \%$, and the second axis accounted for $20.8 \%, P<0.01$, of the variance for the soil samples, respectively. Vectors from joint biplot represent strength and direction of environmental data of $\mathrm{Zn}, \mathrm{As}, \mathrm{Cu}$, $\mathrm{Cr}, \mathrm{Ni}, \mathrm{Pb}$ total concentrations in soils and the technogenic fraction (TGF)

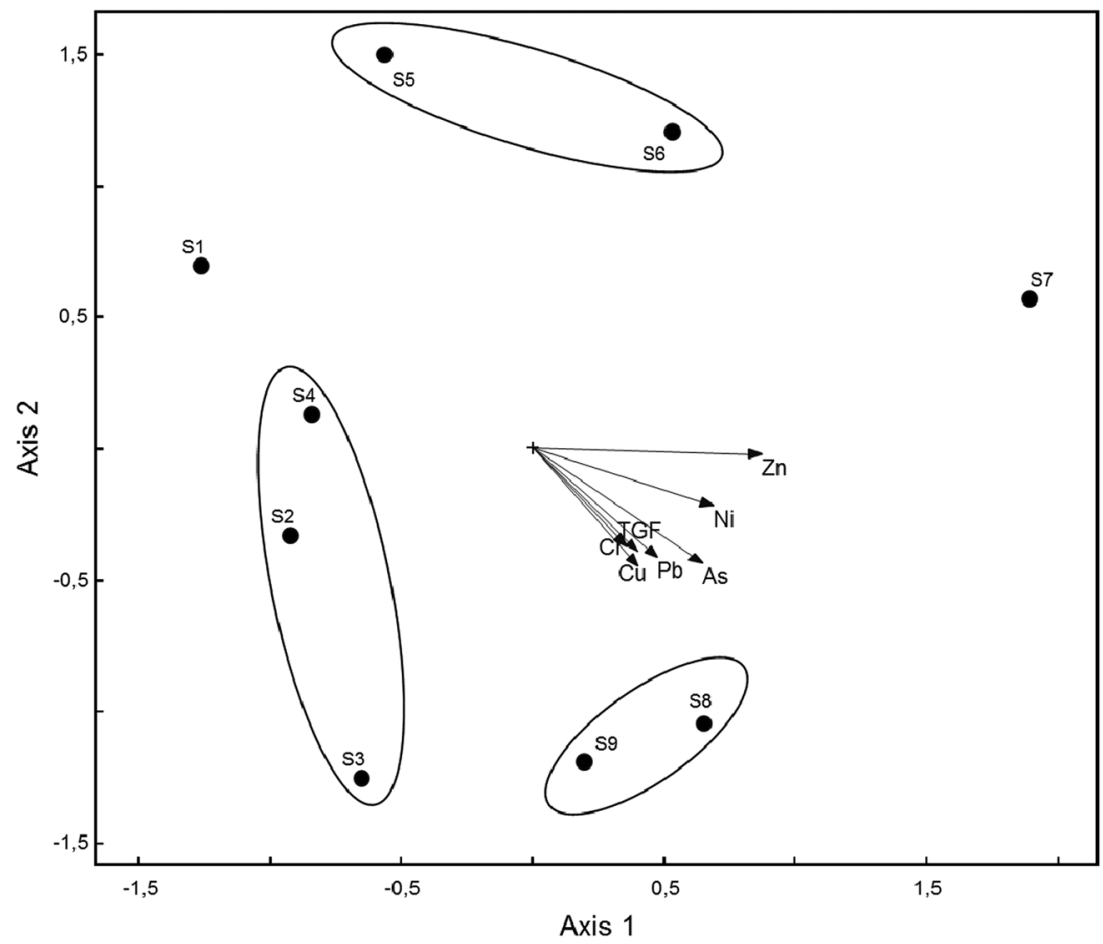


(2015) found DHA activity decrease with the increasing traffic pollution in urban areas of Beijing. However, in the present work, bacterial numbers increased along the anthropogenic gradient, suggesting that despite bacteria being present in greater numbers in the most anthropized soils, their metabolic activity is lower. Phosphatase activity also varied between sites, while urease was weakly affected by anthropization. Both soil enzymes are known to be sensitive to TE (Papa et al. 2010; Bielińska et al. 2013; Hagmann et al. 2015; Minnikova et al. 2017) especially in soils with low organic matter (Calvarro et al. 2014). However, Wang et al. (2011) also reported that urease activity was not inhibited by heavy metals in urban soils in Beijing.

The diversity and structure of soil bacterial communities is shaped by many factors, including the physicochemical properties of soils (Wang et al. 2017). The results of the current work indicate that the higher concentration of TE in most anthropized soils was not translated into a bacterial diversity decline. However, according to CCA, the gradient of anthropization seems to influence the structure of the bacterial communities. Moreover, the concentration of TE in most anthropized soils (S8 and S9) is correlated to BCS, despite their concentrations did not exceed the international standards. These outcomes are in agreement with $\mathrm{Xu}$ et al. (2014) who reported that urbanization influenced the bacterial community composition of soils collected from urban parks in several cities in China. Wang et al. (2017) also reported a close relationship between microbial communities, urbanization, and soil physicochemical properties.

Urban soils play a key role in providing and regulating ecosystem services in urban environments (Morel et al. 2015). In the current work, the microbial abundance and the bacterial diversity were not affected by the anthropization gradient, indicating that the studied urban soils provide a biodiversity regulating service, which is consistent with their pseudo-natural vegetation cover (mainly palm trees). Despite DHA activity decreased along the anthropogenic gradient, suggesting a reduction in the oxidation of soil organic matter by microorganisms (Bolton et al. 1985; Wolińska and Stepniewska 2012; Utobo and Tewari 2015), the levels of $\mathrm{TE}$ and ME found in these soils may be a good source of nutrients for non-food biomass production, which constitute a main ecosystem service that can be provided by urban soils (Morel et al. 2015).

\section{Conclusions}

In general, the increase of anthropogenic activity caused higher accumulation of technic materials and TE in the urban soils of Marrakech city, with the most are anthropized soils being considered Technosols. Despite TE levels are below the international limits allowed, the increase in anthropogenic and technogenic activities throughout time may lead to the accumulation of high levels of these elements in the soil, constituting a huge threat for human and environmental health. All microbiological and biochemical parameters measured in this work were found to be significantly influenced by the anthropogenic inputs. However, they were not systematically inhibited along the anthropogenic gradient excepting the DHA activity. As such, the soil DHA activity may be used as a reliable parameter to determine the effect of human activities on the biological functioning of urban soils.

Acknowledgements The authors would like to thank the scientific collaboration of CBQF under the Fundação Ciência e Tecnologia (FCT) project [UID/Multi/50016/2013].

Funding information The study is financially supported by Centre National de Recherche Scientifique et Techniques [grant no. PPR 22/ 2015] and by the project PhytoSudoe (SOE1/P5/E0189) - Demostração de melhorias na biodiversidade do solo, funcionalidade e serviços ambientais de locais contaminados e/ou degradados sob intervenção de fito-tecnologias dentro da região Interreg Sudoe, funded by FEDER Fundo Europeu de Desenvolvimento Regional under Programa INTERREG.

\section{Compliance with ethical standards}

Conflict of interest The authors declare that they have no conflict of interest.

Publisher's note Springer Nature remains neutral with regard to jurisdictional claims in published maps and institutional affiliations.

\section{References}

Aboudrar W, Schwartz C, Benizri E, Morel JL, Boularbah A (2007) Soil microbial diversity as affected by the rhizosphere of the hyperaccumulator Thlaspicaerulescens under natural conditions. Int J Phytoremediation 9:41-52

Aeliona MC, Davisa HT, McDermottb S, Lawson AB (2009) Soil metal concentrations and toxicity: associations with distances to industrial facilities and implications for human health. Sci Total Environ 407: 2216-2223

Alef K, Nannipieri P (1995) Methods in applied soil microbiology and biochemistry. Academic Press, London

Alekseenko V, Alekseenko A (2014) The abundances of chemical elements in urban soils. J Geochem Explor 147:245-249

Anne P (1945) Sur le dosage rapide du carbone organique des sols. Ann. Agr 2: 161-172

Bae J, Ryu Y (2015) Land use and land cover changes explain spatial and temporal variations of the soil organic carbon stocks in a constructed urban park. Landsc Urban Plan 136:57-67

Baldwin DR, Marshall WJ (1999) Heavy metal poisoning and its laboratory investigation. Ann Clin Biochem 36(3):267-300

Benidire L, Pereira S, Castro P, Boularbah A (2016) Assessment of plant growth promoting bacterial populations in the rhizosphere of metallophytes from Kettara mine Marrakech. Environ Sci Pollut Res 23(21):21751-21765

Bielińska EJ, Kołodziej B, Sugier D (2013) Relationship between organic carbon content and the activity of selected enzymes in urban soils under different anthropogenic influence. J Geochem Explor 129:52_56 
Bolton HJR, Elliott LF, Papendick RI, Bezdicek DF (1985) Soil microbial biomass and selected soil enzyme activities: effect of fertilization and cropping practices. Soil Biol Biochem 17(3):297-302

Boon N, De Windt W, Verstraete W, Top EM (2001) Evaluation of nested PCR-DGGE (denaturing gradient gel electrophoresis) with groupspecific 16S rRNA primers for the analysis of bacterial communities from different wastewater treatment plants. FEMS Microbiol Ecol 39:101-112

Boularbah A, Schwartz C, Bitton G, Morel JL (2006) Heavy metal contamination from mining sites in South Morocco:1. Use of a biotest to assess metal toxicity of tailings and soils. Chemosphere 63:802-810

Braun B, Böckelmann U, Grohmann E, Szewzyk U (2006) Polyphasic characterization of the bacterial community in an urban soil profile with in situ and culture-dependent methods. Appl Soil Ecol 31:267279

Bullock P, Gregory P (1991) Soils in the urban environment. Scientific Publication, Blackwell

Burghardt W, Morel JL, Zhang G-L (2015) Development of the soil research about urban, industrial, traffic, mining and military areas (SUITMA). Soil Sci Plant Nutr 61:3-21

Calvarro LM, Santiago-Martin A, Gomez JQ, Gonzalez-Huecas C, Quintana JR, Vazquez A, Lafuente AL, Rodriguez-Fernandez TM, Vera RZ (2014) Biological activity in metal-contaminated calcareous agricultural soils: the role of the organic matter composition and the particle size distribution. Environ Sci Pollut Res 21(9):61766187

Charzyński P, Plak A, Hanaka A (2017) Influence of the soil sealing on the geoaccumulation index of heavy metals and various pollution factors. Environ Sci Pollut Res 24(5):4801-4811

Concas A, Ardau C, Cristini A, Zuddas P, Cao G (2006) Mobility of heavy metals from tailings to stream waters in a mining activity contaminated site. Chemosphere 63:244-253

Dai J, Becquer T, Rouiller JH, Reversat G, Bernhard-Reversat F, Lavelle $P$ (2004) Influence of heavy metals on $\mathrm{C}$ and $\mathrm{N}$ mineralisation and microbial biomass in $\mathrm{Zn}-\mathrm{Pb}$ - $\mathrm{Cu}$ - and $\mathrm{Cd}$-contaminated soils. Appl Soil Ecol 25:99-109

Davis AP, Shokouhian M, Ni S (2001) Loading estimates of lead, copper, cadmium, and zinc in urban runoff from specific sources. Chemosphere 44(5):997-1009

Ding Y, Liu Y, Liu S, Li Z, Tan X, Huang X, Zeng G, Zhou L, Zheng B (2016) Biochar to improve soil fertility. A review. Agron. Sustain. Dev. 36:36. https://doi.org/10.1007/s13593-016-0372-z

Eivazi F, Tabatabai M (1977) Phosphatases in soils. Soil Biol Biochem 9: $167-172$

El Faiz M (2002) Marrakech patrimoine en péril. Actes Sud / Edit, Arles

El Khalil H, El Hamiani O, Bitton G, Ouazzani N, Boularbah A (2008a) Heavy metal contamination from mining sites in South Morocco: monitoring metal content and toxicity of soil runoff and groundwater. Environ Monit Assess 136(1-3):147-160

El Khalil H, Schwartz C, El Hamiani O, Kubiniok K, Morel JL, Boularbah A (2013) Distribution of major elements and trace metals as indicators of technosolisation of urban and suburban soils. J Soils Sediments 13:519-530

El Khalil H, Schwartz C, Elhamiani O, Kubiniok J, Morel JL, Boularbah A (2008b) Contribution of technic materials to the mobile fraction of metals in urban soils in Marrakech (Morocco). J Soils Sediments 1: $17-22$

El Khalil H, Schwartz C, Elhamiani O, Sirguey C, Kubiniok J, Boularbah A (2016) How physical alteration of technic materials affects mobility and phytoavailabilty of metals in urban soils? Chemosphere $152: 407-414$

Farrell M, Griffith GW, Hobbs PJ, Perkins WT, Jones DL (2010) Microbial diversity and activity are increased by compost amendment of metal-contaminated soil. FEMS Microbiol Ecol 71:94-105
Filip Z (2002) International approach to assessing soil quality by ecologically-related biological parameters. Agric Ecosyst Environ $88: 169-174$

Gadd G (1992) Metals and microorganisms: a problem of definition. FEMS Microbiol Lett 100:197-204

Gevorgyan GA, Ghazaryan KA, Movsesyan HS, Zhamharyan HG (2017) Human health risk assessment of heavy metal pollution in soils around Kapan mining area, Armenia. Electron J Nat Sci 2:29-33

Gil-Sotres F, Trasar-Cepeda C, Leiros MC, Seoane S (2005) Different approaches to evaluating soil quality using biochemical properties. Soil Biol Biochem 37:877-887

Godefroid S, Monbaliu D, Koedam N (2007) The role of soil and microclimatic variables in the distribution patterns of urban wasteland flora in Brussels Belgium. Landsc. Urban Plan 80:45-55

Gülser F, Erdoğan E (2008) The effects of heavy metal pollution on enzyme activities and basal soil respiration of roadside soils. Environ Monit Assess 145:127-133

Gu Y, Wang P, Kong CH (2009) Urease, invertase, dehydrogenase and polyphenoloxidase activities in paddy soils influenced by allelopathic rice variety. Eur J Soil Biol 45:436-441

Hafeez F, Spor A, Breuil MC, Schwartz C, Martin-Laurent F, Philippot L (2012) Distribution of bacteria and nitrogen-cycling microbial communities along constructed technosol depth-profiles. J Hazard Mater 15:231-232 88-97

Hagmann DF, Goodey NM, Mathieu C, Evans J, Aronson M, Gallagher F, Krumins JA (2015) Effect of metal contamination on microbial enzymatic activity in soil. Soil Biol Biochem 91:291-297

Haut-commissariat au plan (2014) Ressensement général de la population et de l'habitat-2014. http://www.hcp.ma/. Accessed 30 March 2017

Hayat S, Ahmad I, Azam ZM, Ahmad A, Inam A, Samiullah (2002) Effect of long-term application of oil refinery wastewater on soil health with special reference to microbiological characteristics. Bioresour Technol 84:159-163

Hu B, Jia X, Hu J, Xu D, Xia F, Li Y (2017) Assessment of heavy metal pollution and health risks in the soil-plant-human system in the Yangtze River Delta, China. Int J Environ Res Public Health 14:118

Hulisz P, Charzyński P, Greinert A (2018) Urban soil resources of medium-sized cities in Poland: a comparative case study of Torun and Zielona Góra. J Soils Sediments 18(2):358-372

Ita RE, Anwana ED (2017) Geochemical assessment of heavy metal contamination in rural and urban wetlands in Akwa Ibom State, Nigeria. NY Sci J 10(11):43-51 ISSN 1554-0200 (print); ISSN 2375-723X (online)

IUSS Working Group WRB (2015) World Reference Base for Soil Resources 2014, Update 2015. International soil classification system for naming soils and creating legends for soil maps. World Soil Resources Reports No. 106. FAO, Rome

Jim CY (1998) Soil characteristics and management in an urban park in Hong Kong. J Environ Manag 22(5):683-695

Joimel S, Cortet J, Jolivet C, Saby N, Chenot ED, Branchu P, Consalès JN, Lefort C, Morel JL, Schwartz C (2016) Physico-chemical characteristics of topsoil for contrasted forest, agricultural, urban and industrial land uses in France. Sci Total Environ 545-546:40-47

Joimel S, Schwartz C, Hedde M, Kiyota S, Henning Krogh P, Nahmani J, Pérès G, Vergnes A, Cortet J (2017) Urban and industrial land uses have a higher soil biological quality than expected fromphysicochemical quality. Sci Total Environ 584-585:614-621

Kabata-Pendias A (2011) Trace elements in soils and plants. CRC Press, Florida

Klose S, Makeschin F (2004) Chemical properties of forest soils along a fly-ash deposition gradient in eastern Germany. Eur J Forest Res 123:3-11

Laidlaw MAS, Filippelli GM (2008) Resuspension of urban soils as a persistent source of lead poisoning in children: a review and new directions. Appl Geochem 23:2021-2039 
Lalande R, Gagnon B, Royer I (2009) Impact of natural or industrial liming materials on soil properties and microbial activity. Can J Soil Sci 89:209-223

Lane DJ (1991) 16S/23S sequencing. In: Stackebrandt E, Goodfellow M (eds) Nucleic acid techniques in bacterial systematics. Wiley, Chichester, pp 171-204

Levin MJ, Kim KHJ, Morel JL, Burghardt W, Charzynski P, Shaw RK, IUSS Working Group SUITMA (2017) Soils within Cities. Schweizerbart Science Publishers, Stuttgart

Li T, Meng L, Herman U, Lu Z, Crittenden J (2015) A survey of soil enzyme activities along major roads in Beijing:the implications for traffic corridor green space management. Int J Environ Res Public Health 12:12475-12488

Lorenz K, Preston CM, Kandeler E (2006) Soil organic matter in urban soils. Estimation of elemental carbon by thermal oxidation and characterization of organic matter by solid-state 13C nuclear magnetic resonance (NMR) spectroscopy. Geoderma 130:312-323

Lovett GM, Traynor MM, Pouyat RV, Carreiro MM, Zhu WG, Baxter JW (2000) Atmospheric deposition to oak forests along an urban-rural gradient. Environ Sci Technol 34:4294-4300

Luo XS, Ding J, Bo X, Wang YJ, Li HB, Yu S (2012) Incorporating bioaccessibility into human health risk assessments of heavy metals in urban park soils. Sci Total Environ 424:88-96

Magiera T, Strzyszcz Z, Rachwal M (2007) Mapping particulate pollution loads using soil magnetometry in urban forests in the upper Silesia industrial region Poland. For Ecol Manag 248:36-42

Margesin R, Płaza GA, Kasenbacher S (2011) Characterization of bacterial communities at heavy-metal-contaminated sites. Chemosphere $82: 1583-1588$

Meuser H (2010) Contaminated urban soils. Environmental pollution, vol 18. springer, Netherlands

Minnikova T, Denisova T, Mandzhieva S, Kolesnikov S, Minkina T, Chaplygin V, Burachevskaya MV, Sushkova SN, Bauer TV (2017) Assessing the effect of heavy metals from the Novocherkassk power station emissions on the biological activity of soils in the adjacent areas. J Geochem Explor 174:70-78

Moreira H, Marques APGC, Franco AR, Rangel AOSS, Castro PML (2014) Phytomanagement of cd-contaminated soils using maize (Zea mays L.) assisted by plant growth-promoting rhizobacteria. Environ Sci Pollut Res 21:9742-9753

Morel JL, Schwartz C, Florentin L, Kimpe C (2005) Urban soils. In: Hillel D (ed) Encyclopedia of Soils in the Environment, Elsevier Ltd. Academic Press, London, pp 202-208

Morel JL, Chenu C, Lorenz K (2015) Ecosystem services provided by soils of urban, industrial, traffic, mining, and military areas (SUITMAs). J Soils Sediments 15:1659-1666

Muller G (1969) Index of geoaccumulation in sediments of the Rhine River. J Geol 2:109-118

Muyzer G, De Waal EC, Uiterlinden AG (1993) Profiling of complex microbial populations by denaturating gradient gel electrophoresis analysis of polymerase chain reaction amplified genes coding for 16S rRNA. Appl Environ Microbiol 59:695-700

Nannoni F, Rossi S, Protano G (2014) Soil properties and metal accumulation by earthworms in the Siena urban area (Italy). Appl Soil Ecol 77:9-17

Newbound M, Mccarthy MA, Lebel T (2010) Fungi and the urban environment: a review. Landsc Urban Plan 96:138-145

Oliveira A, Pampulha ME (2006) Effects of long-term heavy metal contamination on soil microbial characteristics. J Biosci Bioeng 102: 157-161

Papa S, Bartoli G, Pellegrino A, Fioretto A (2010) Microbial activities and trace element contents in an urban soil. Environ Monit Assess 165:193-203

Pan J, Yu L (2011) Effects of Cd or/and Pb on soil enzyme activities and microbial community sructure. Ecol Eng 37:1889-1894
Pereira SIA, Castro PML (2014) Phosphate-solubilizing rhizobacteria enhance Zea mays growth in agricultural P-deficient soils. Ecol Eng 73:526-535

Pouyat RV, Szlavecz K, Yesilonis ID, Groffman PM, Schwarz K (2010) Chemical, physical, and biological characteristics of urban soils. In: Aitkenhead-Peterson J, Volder A (eds) Urban ecosystem ecology, agronomy monographs 55. Madison, pp 119-152

Pouyat RV, Yesilonis ID, Golubiewski NE (2009) A comparison of soil organic carbon stocks between residential turf grass and native soil. Urban Ecosyst 12:45-62

Raciti SM, Pouyat RV, Fahey TJ, Pickett ST, Groffman PM, Jenkins JC, Cadenasso ML (2011) Accumulation of carbon and nitrogen in residential soils with different land-use histories. Ecosystems 14:287297

Rauch JN, Pacyna JM (2009) Earth's global Ag, Al, Cr, Cu, Fe, Ni, Pb, and Zn cycles. Global Biogeochem CY 23(2):1-16

Salazar S, Sánchez L, Alvarez J, Valverde A, Galindo P, Igual JM, Peix A, SantaRegina I (2011) Correlation among soil enzyme activities under different forest system management practices. Ecol Eng 37: $1123-1131$

Seto KC, Fragkias M, Güneralp B, Reilly MK (2011) A meta-analysis of global urban land expansion. PLoS One 6(8):e23777. https://doi. org/10.1371/journal.pone.0023777

Stefanowicz AM, Kapusta P, Szarek-Łukaszewska G, Grodzińska K, Niklińska M, Vogt RD (2012) Soil fertility and plant diversity enhance microbial performance in metal-polluted soils. Sci Total Environ 439:211-219

Tabatabai MA, Bremner JM (1972) Assay of urease activity in soils. Soil Biol Biochem 4:479-487

Tabatabai MA, Bremner JM (1969) Use of p-nitrophenyl phosphate for assay of soil phosphatase activity. Soil Biol Biochem 1:301-307

Thalmann A (1968) Zur Methodik der Bestimmung der Dehydrogenaseaktivitat im Boden mittels Triphenyltetrazoliumchlorid (TTC). In: Alef K, Nannipieri P (eds) Methods in Applied Soil Microbiology and Biochemistry. Academic Press, London, pp 228-230

United Nations (2014) Department of Economic and Social Affairs, Population Division. World Urbanization Prospects: The 2014 Revision, Highlights (ST/ESA/SER.A/352)

Utobo EB, Tewari L (2015) Soil enzymes as bioindicators of soil ecosystem status. Appl Ecol Environ Res 13(1):147-169

Wang M, Markert B, Shen W, Chen W, Peng C, Ouyang Z (2011) Microbial biomass carbon and enzyme activities of urban soils in Beijing. Environ Sci Pollut Res 18:958-967

Wang H, Marshall CW, Cheng M, Xu H, Li H, Yang X, Zheng T (2017) Changes in land use driven by urbanization impact nitrogen cycling and the microbial community composition in soils. Sci Rep 7: 44049. https://doi.org/10.1038/srep44049

Wilbaux Q (2001) La médina de Marrakech Formation des espaces urbains d'une ancienne capitale de Maroc. L'Harmattan, Paris

Wolińska A, Stępniewska Z (2012) Dehydrogenase activity in the soil environment, dehydrogenases, Canuto RA (ed). InTech. https://doi. org $/ 10.5772 / 48294$

Yang JL, Zhang GL (2015) Formation, characteristics and ecoenvironmental implications of urban soils - a review. Soil Sci Plant Nutr 61:30-46

Yesilonis ID, Pouyat RV, Neerchal NK (2008) Spatial distribution of metals in soils in Baltimore, Maryland: role of native parent material, proximity to major roads, housing age and screening guidelines. Environ Pollut 156(3):723-731

Yuangen Y, Campbell C, Clark L, Cameron C, Paterson E (2006) Microbial indicators of heavy metal contamination in urban and rural soils. Chemosphere 63:1942-1952

Xu HJ, Li S, Su JQ, Nie S, Gibson V, Li H, Zhu YZ (2014) Does urbanization shape bacterial community composition in urban park soils? A case study in 16 representative Chinese cities based on the pyrosequencing method. FEMS Microbiol Ecol 87:182-192 